\title{
Meram Dere Vadisi'nin (Konya) Floristik Özellikleri
}

\author{
Recep Bozyiğit ${ }^{1 *}$, Baştürk Kaya ${ }^{2}$ \\ ${ }^{1}$ Necmettin Erbakan Üniversitesi, Ahmet Keleşoğlu Eğitim Fakültesi, Coğrafya Eğitimi, Konya, Türkiye (ORCID:0000-0002-9790-1168) \\ ${ }^{2}$ Necmettin Erbakan Üniversitesi, Ahmet Keleşoğlu Eğitim Fakültesi, Biyoloji Eğitimi, Konya, Türkiye (ORCID:0000-0002-4801-4386)
}

(İlk GelişTarihi 10 Kasım 2019 ve Kabul Tarihi 7 Aralık 2019)

(DOI: 10.31590/ejosat.649509)

ATIF/REFERENCE: Bozyiğit, R. \& Kaya, B. (2019). Meram Dere Vadisi'nin (Konya) Floristik Özellikleri. Avrupa Bilim ve Teknoloji Dergisi, (17), 888-900.

\section{$\ddot{O} \mathbf{z}$}

"Meram Dere Vadisi'nin (Konya) Floristik Özellikleri” adlı çalışmanın amacı, vadi ve yakın çevresinin floristik özelliklerini, bu özelliklerin ortaya çıkmasında etkili olan faktörleri ortaya koymaktır. Çalışmanın gerçekleştirilmesi için öncelikle konu ile ilgili toprak, jeoloji, amenajman haritaları ile raporlardan yararlanılmıştır. Veri toplama ve hazırlama sürecinden sonra saha çalışmalarına geçilmiştir. Farklı zamanlarda gerçekleştirilen saha çalışmaları ile bitki örtüsünün güncel durumu belirlenmiş ve haritalandırılmıştır. Ayrıca vadi ve çevresindeki bitki türlerine etki eden süreçler ve etki değerleri yerinde gözlemlenerek kayıt altına alınmıştır. Çalışmanın topoğrafya, toprak ve bitki örtüsü haritaları, Mapp İnfo 9.5 programı kullanılarak hazırlanmıştır. Son aşamada ise elde edilen tüm bilgiler coğrafya biliminin ilkeleri doğrultusunda analiz edilerek yazım aşaması gerçekleştirilmiştir.

Araştırma sahası floristik yapı bakımından ilginç özelikler göstermektedir. Bu özelliklerin ortaya çıłmasında doğal ve antropojenik faktörlerin etkileri görülmektedir. Özellikle Meram Dere Vadisi’nin doğu-batı yönlü uzantılı yüksek dağlık ve tepelik alanlarla çevrili bir yapı oluşturması bu sahanın bir mikroklima özelliği göstermesine yol açmıştır. Bu durum, bitki örtüsünü olumlu yönde etkilemiştir. Akdeniz elementi olan Menengiç (Pistacia terebinthus) sıklıkla rastlanan bir tür olarak bu kesimlerde topluluk halinde yer almaktadır. Ayrıca farklı jeolojik dönemlere ait ana kaya üzerinde oluşmuş topraklar, bitki örtüsünün de niteliğinin değişmesine neden olmuştur. Menengiç (Pistacia terebinthus) ofiolit kayaçların bulunduğu kesimlerde daha seyrek ve daha bodurlaşmış olarak gelişirken; kalker, dolomitik kalker anakaya üzerinde hem sayı olarak artmış, hem de daha iyi bir fizyonomiye sahip olduğu tespit edilmiştir.

Meram Dere Vadisi'nin bitki örtüsü; orman, çalı ve step vejetasyonundan oluşmaktadır. Meram Dere Vadi tabanında ve yakın çevresinde nemcil; vadi yamaçlarına doğru kurakçıl çalı ve orman; plato yüzeylerinde orman ağaçları, çalı ve step vejetasyonunun yoğunlaştığı görülmektedir.

Sonuç olarak Meram Dere Vadisi'nde bitki örtüsünün şekillenmesinde mikroklima, topografya, anakaya, toprak, hidroğrafik şartların etkisi yanında antropojenik faktörlerin de etkili olduğu görülmüştür.

Anahtar Kelimeler: Meram Dere, Vadi, Mikroklima, Konya, Floristik,

\section{Floristic Features of Meram Dere Valley (Konya)}

\begin{abstract}
The aim of the study entitled "Floristic Features of Meram Dere Valley (Konya)" is to determine floristic characteristics of the valley and its immediate surroundings and the factors playing a role in the emergence of these features. Hence, first reports about the soil, geology, management maps \& reports were employed for the present study. Subsequent to the data collection and preparation process, field studies were begun. The current status of the present vegetation was determined and mapped with field studies conducted at various times. Moreover the conditions influencing the valley and surrounding plant species and their impact values were observed on-site and recorded. Topography, soil and vegetation maps of the study were prepared by using Mapp Info 9.5 program. At the final stage, all the information obtained was analyzed according to the principles of geography and the present manuscript written.

The research area has interesting features in terms of its floristic structure. The effects of natural and anthropogenic conditions are vivid in emergence of these features. Meram Dere Valley is a structure surrounded by high mountainous and hilly areas extending in the east-west direction. This fact has in particular led to the formation of a microclimate with a positive impact on the vegetation. Pistacia terebinthus, which is a Mediterranean element, is a common species. In addition, the soils formed on the bedrock belonging to different geological periods caused the flora as well as their features to change. Whereas pistacia terebinthus is less frequent and dwarfed on the ophiolite rocks, on limestone and dolomitic limestone bedrock it is more frequent and has a better physiognomy.
\end{abstract}

\footnotetext{
Sorumlu Yazar: Necmettin Erbakan Üniversitesi, Ahmet Keleşoğlu Eğitim Fakültesi, Coğrafya Eğitimi, Konya, Türkiye, ORCID:0000-0002-97901168,fethiye.kemer@gmail.com 


\section{European Journal of Science and Technology}

The vegetation of Meram Dere Valley consists of forest, shrub and steppe vegetation. The vegetation at the bottom and nearby area consists of humid, the versants of xerophilous plant and forest, and the plateaus of forest trees, shrubs and of steppe vegetation.

In conclusion, anthropogenic factors along with microclimate, topography, bedrock, soil, and hydrographic conditions were effective in the formation of the vegetation in Meram Dere Valley in Konya.

Key Words: Meram Dere, Valley, Microclimate, Konya, Floristic

\section{Giriş}

Günümüzde bitki türleri, yayılışı ve ekolojik isteklerine yönelik çalışmalar bulunmaktadır (Dural, 1984; Güngördü, 1985; Çetik, 1985; Avc1, 1993-1996, 1998a, 1998b; Günal 1998-1999). Ancak bu çalışmaların sürdürebilirliği zamanla orantılı olarak değişmektedir. Türkiye'nin floristik açıdan zengin olması araştırmacıların azmini arttırmakta, her yıl Türkiye Florasına yeni bitki türleri eklenmektedir. Bu açıdan, Meram Dere Vadisi sahip olduğu floristik özellikleri ile dikkat çekmektedir.

Meram Dere Vadisi, İç Anadolu Bölgesi'nde Konya ili sınırları içerisinde yer almaktadır. Vadi, 38 45'02”-49 30'05" doğu meridyenleri arasında bulunmaktadır. Vadiyi, kuzeyde Altınapa Baraj Gölü ile Keçili Deresi Vadisi, Doğuda Konya Ovası, güneyde Loras Dağı (2051 m) ve batısında Çaldağı sınırlamaktadır (Şekil 1).

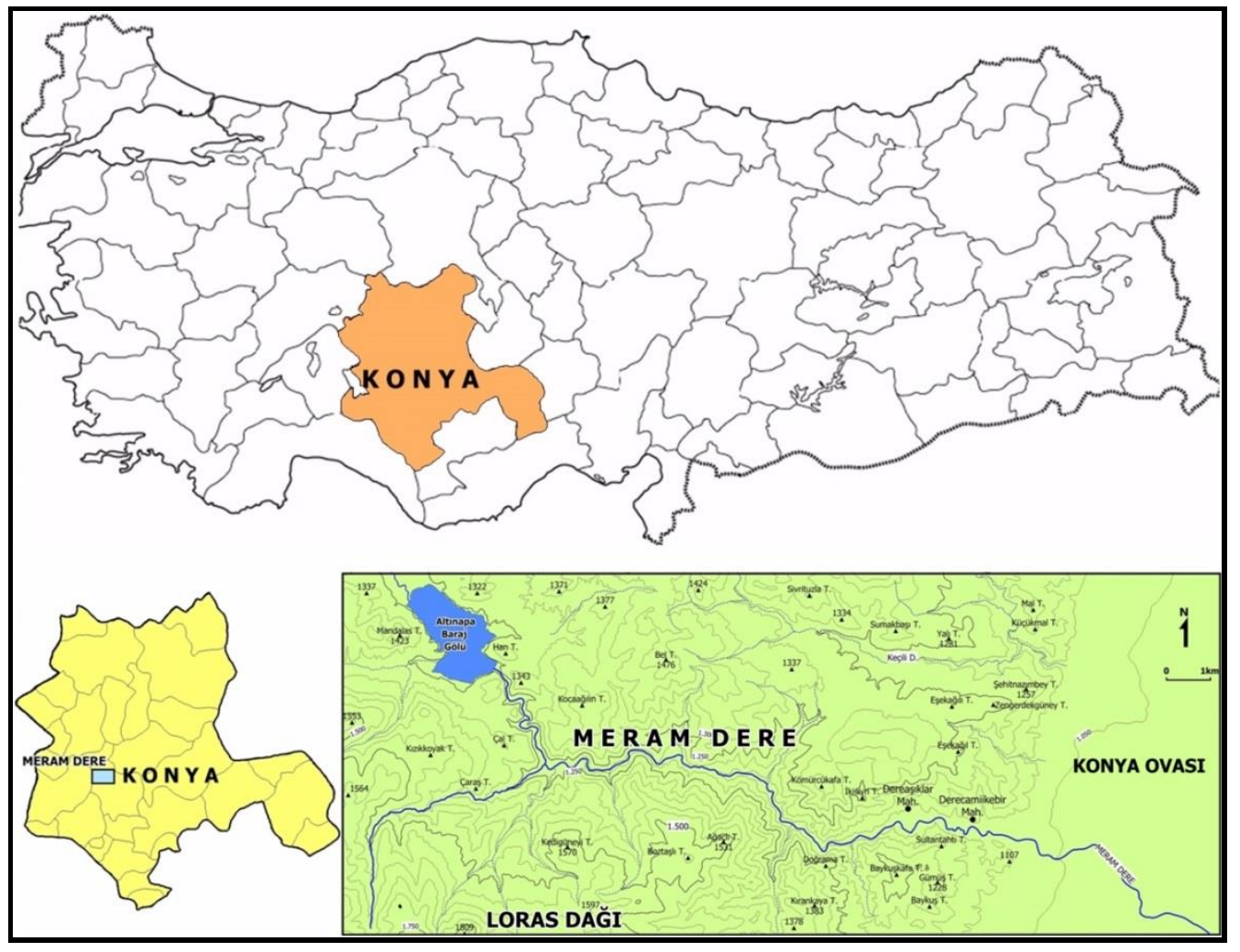

Şekil 1. Meram Dere Vadisi’nin Lokasyon Haritası.

Meram Dere Vadisi, Altınapa Barajı Havzası'nın sularını Konya Ovası’na boşaltan bir vadidir. Vadi, Konya Kapalı Havzası içerisinde farklı iki alt hidrolojik havzayı birbirine bağlamasının yanında oluşum, gelişim, iklim ve bitki türleri açısından farklılıklar göstermektedir. Meram Dere Vadisi ile ilgili çalışmalar arasında jeolojisine yönelik olanlar geniş yer tutmaktadır. Bu konuda Göğer ve Kıral (1973) vadide en yaşlı birimlerin Alt-Orta Trias yaşlı kalker ve dolomitler olduğunu belirtmişlerdir. Güyer vd. (1998) ile Süzer vd. (2011) Üst Kretase-Alt Paleosen aralığında çökelmiş olan kumtaşı, silttaşı, peridotit, gabro ve çörtlü kalkerlerin vadinin doğu kesiminde her iki yamaçta yüzeylediğini ifade etmişlerdir. Meram Dere Vadisi çevresindeki plato yüzeylerin Orta Miosen-Alt Pliosen yaşlı kumtaşı, çakıltaşı, kiltaşı, killi kalker, kalker, tüf ve aglomeralardan oluştuğunu ileri sürmüşlerdir (Bulduk vd. 2006; Şenel-Pehlivan, 2016).

\section{Materyal ve Metot}

“Meram Dere Vadisi'nin (Konya) Floristik Özellikleri” adlı çalışma, vadi ve yakın çevresinin floristik özelliklerini, bu özelliklerin ortaya çıkmasında etkili olan faktörleri ortaya koymayı hedeflemektedir. Çalışmanın gerçekleştirilmesi için öncelikle konu ile ilgili toprak, jeoloji, amenajman haritaları ve raporlardan yararlanılmıştır. Veri toplama ve hazırlama sürecinden sonra saha çalışmalarına geçilmiştir. Farklı zamanlarda gerçekleştirilen saha çalışmaları ile bitki örtüsünün güncel durumu belirlenmiş ve haritalandırılmıştır. Ayrıca vadi ve çevresindeki bitki türlerine etki eden süreçler ve etki değerleri yerinde gözlemlenerek kayıt altına alınmıştır. Çalışmanın 
topoğrafya, toprak ve bitki örtüsü haritaları, Mapp İnfo 9.5 programı kullanılarak hazırlanmıştır. Son aşamada ise elde edilen tüm bilgiler coğrafya biliminin ilkeleri doğrultusunda analiz edilerek yazım aşaması gerçekleştirilmiştir.

\section{Araştırma Bulguları ve Tartışma}

\subsection{Meram Dere Vadisi'nin Floristik Özelliklerine Etki Eden Doğal Faktörler}

Meram Dere Vadisi'nin bitki örtüsünün ortaya çıkması ve şekillenmesinde; jeolojik, jeomorfolojik, toprak, iklim ve hidrografik faktörlerin etkileri görülmektedir.

Meram Dere Vadisi ve çevresinde Alt-Orta Trias'dan günümüze kadar farklı jeolojik devirlerde oluşmuş formasyonlara rastlanmaktadır. Alt Orta Trias yaşlı kalker ve dolomitler, Meram Dere Vadisi'nin batısında dar bir sahada yer almaktadır. Orta Trias-Üst Jura yaş aralığında çökelmiş rekristalize kalker, dolomitik kalker ve dolomitlerden oluşan formasyon "Loras Kireçtaşı" olarak adlandırılmaktadır (Göğer ve Kıral, 1973). Meram Dere Vadisi'nin batısında dolomit ve kalkerlerin yer yer 700 metre kalınlığa ulaştığı tespit edilmiştir (Güyer vd, 1998:10). Orta Jura-Kretase yaşlı radyolaryalı mikritler Loras Dağı'nın kuzeydoğu yamaçları ile Meram Dere Vadisi'nin kuzey yamaçlarında parçalı bir dağılış göstermektedir (Şenel-Pehlivan, 2016:11: Şenel, M., Dalkılıç, H.2016). Dereaşıklar Mahallesi'nin kuzey kesiminde ofiolit karmaşı̆̆ı arasında farklı jeolojik dönemlere ait kalker, peridotit, gabro, serpantinit, radyolorit, kumtaşı, silttaşı, ve volkanit bloklarının yer aldığı tektonik karmaşık yer alır. Üst Kretase-Alt Paleosen aralığında çökelmiş birimler, Meram Dere Vadisi'nin kuzey ve güney kesimlerinde yer almaktadır (Güyer vd.1998:11-12). Çayırbağı ofiolitlerinin toplam kalınlığı en fazla 400 m kadardır (Süzer ve dĭ̆. 2011). Çayırbağı ofiolitleri üzerini Neojen yaşlı birimler açılı uyumsuz olarak örtmektedir.

Meram Dere ve çevresini oluşturan arazide "Dilekçi Formasyonu” olarak adlandırılan Miosen-Alt Pliosen yaşlı kumtaşı, çakıltaşı, kiltaşı, killi kalker, kalker, tüf, aglomera ve genellikle andezitik-dasitik lavlar geniş sahalar kaplamaktadır (Bulduk vd., 2006:18). Pleistosen yaşlı formasyonlar, Meram Dere Vadisi’nin Konya Ovası'na açıldı ̆̆ı kesimde yer almaktadır. Çok az tutturulmuş silttaşı, kumtaşı, çakıltaşı ve konglomeralardan oluşur. Holosen yaşlı alüvyonlara Meram Dere vadi tabanında dar alanlarda rastlanmaktadır. Buradaki alüvyonların kum, çakıl ve silt boyutundaki malzemeden oluştuğu gözlenmektedir (Bozyiğit, 2018:34-35).

Meram Dere Vadisi ve çevresini oluşturan arazi, jeomorfolojik açıdan; yüksek ve alçak platolar, Meram Dere Vadisi ve etek ovası olmak üzere üç ana birime ayrılmaktadır (Şekil 2). Araştırma sahasındaki plato sahaları Üst Pliosen’den günümüze kadar ki dönemde bir taraftan tektonik olayların, diğer taraftan erozyonal faaliyetin bir sonucu olarak oluşmuştur (Güyer vd.1998: Karbıyıkoğlu, 2003). Plato yüzeyi yer yer kıvrımlı ve kırıklı yapı özelliği gösterir. Akarsu ve yüzey erozyonu ile şekillenen saha dik yamaçlı vadilerle parçalanmıştır. Meram Dere Vadisi, önceleri Üst Miosen-Alt Pliosen yaşlı formasyonlar üzerinde oluşmuş daha sonra tektonizma ve Eski Konya Gölü denetimine giren saha, Konya Gölü’ndeki seviye değişimlerine bağlı olarak yatağına gömülmüştür. Meram Dere Vadisi’nin doğu kesimindeki alçak plato sahası ile ova tabanı arasında kuzey-güney yönlü alüvyon yelpazelerin meydana getirdiği etek ovası yer alır. Bu ovanın oluşumunda flüviyal, tektonik ve limnik süreçlerin etkili olduğu sonucuna ulaşılmıştır.

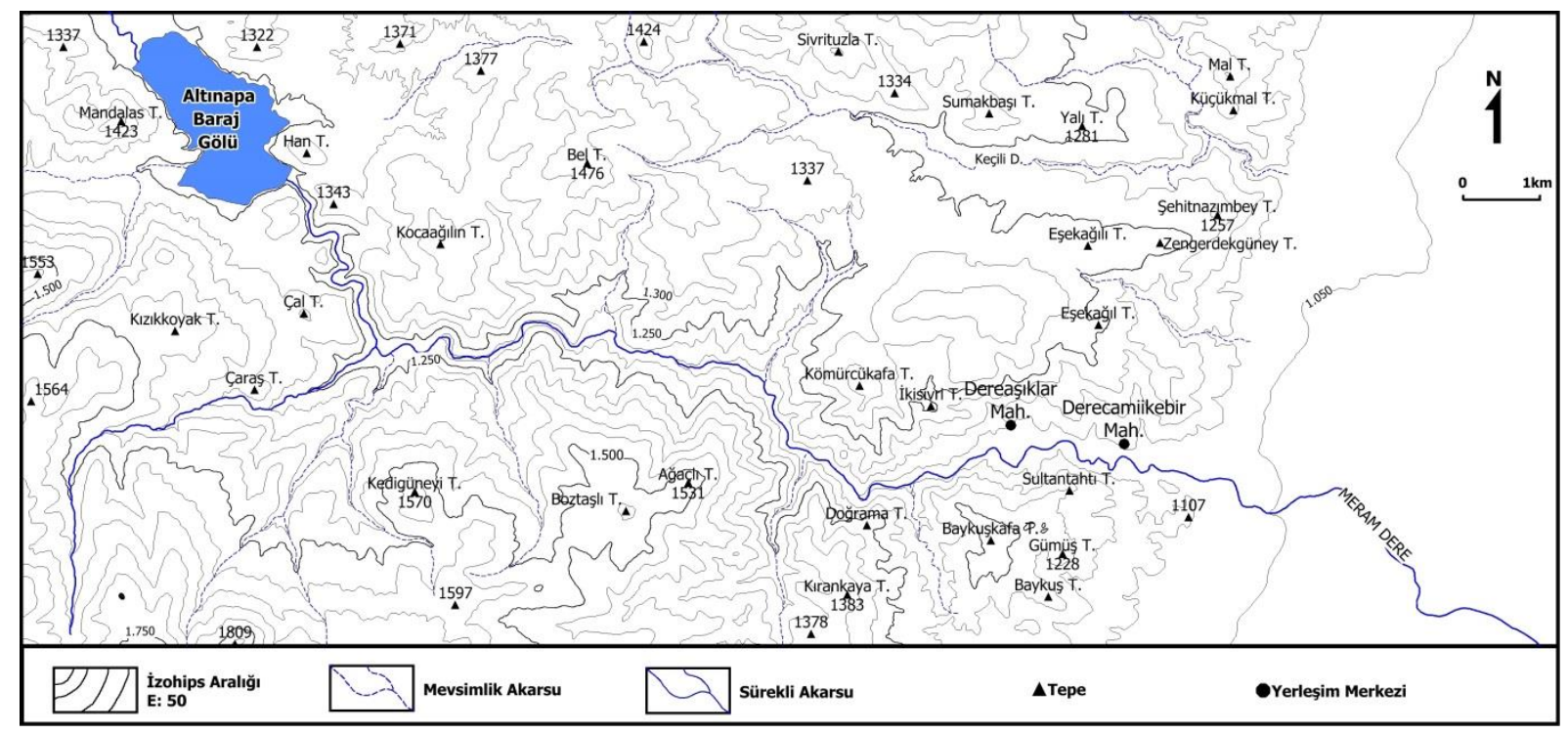

Şekil 2. Meram Dere Vadisi ve Çevresinin Topografya Haritası.

Araştırma sahasının yüksek kesimlerinde yer alan akarsuların, Eski Konya Gölü’ndeki seviye alçalmaları ve tektonizmaya bağlı olarak aşındırma güçleri artmış ve yataklarına gömülmüşlerdir.

Meram Dere Vadisi ve çevresinde yedi büyük toprak grubu yer almaktadır (Tarım ve Köy İşleri Bakanlığı, Köy Hizmetleri Müdürlüğü, 1992). Bunlar: Alüvyal topraklar: akarsu orijinli depozitlerden meydana gelen, profilinde çeşitli katlar bulunduran genç ve derin topraklardır. A ve C horizonuna sahiptirler. Meram Dere Vadisi'nin Konya Ovası'na açıldığı alüvyal yelpazeler üzerinde gelişme göstermiştir (Şekil 3). Kolüviyal Topraklar: alüviyal topraklara bitişik olarak alüviyallerle yüksek arazi toprakları arasında yer 


\section{European Journal of Science and Technology}

almaktadır. Kırmızımsı Kestanerengi Topraklar: A, B ve C profili ile dikkat çeker. Kırmızı kestane rengi topraklar orman, çalılık ve kuru tarım olarak kullanılmaktadır. Kireçsiz Kahverengi Orman Toprakları: Meram Dere Vadisi ve çevresinde topoğrafyanın dağlık ve tepelik, eğimin fazla olduğu kesimlerde görülmektedir. Kırmızımsı Kahverengi Topraklar: Meram Dere Vadisi ve çevresinde en yaygın toprak tipini oluşturur (Şekil 3). Dalgalı bir plato yüzeyinde A, B ve C profilli zonal topraklardır. Kireçsiz Kahverengi Topraklar: dalgalı tepelik sahalarda A, B ve C profilli zonal topraklardır. Kahverengi Topraklar: Meram Dere Vadisi'nin kuzeydoğusunda yer alır. Step bitki örtüsü altında oluşmuş sığ topraklardır. Kumtaşı, çakıltaşı, kalker ve tüflü ana materyal üzerinde gelişme göstermiştir.

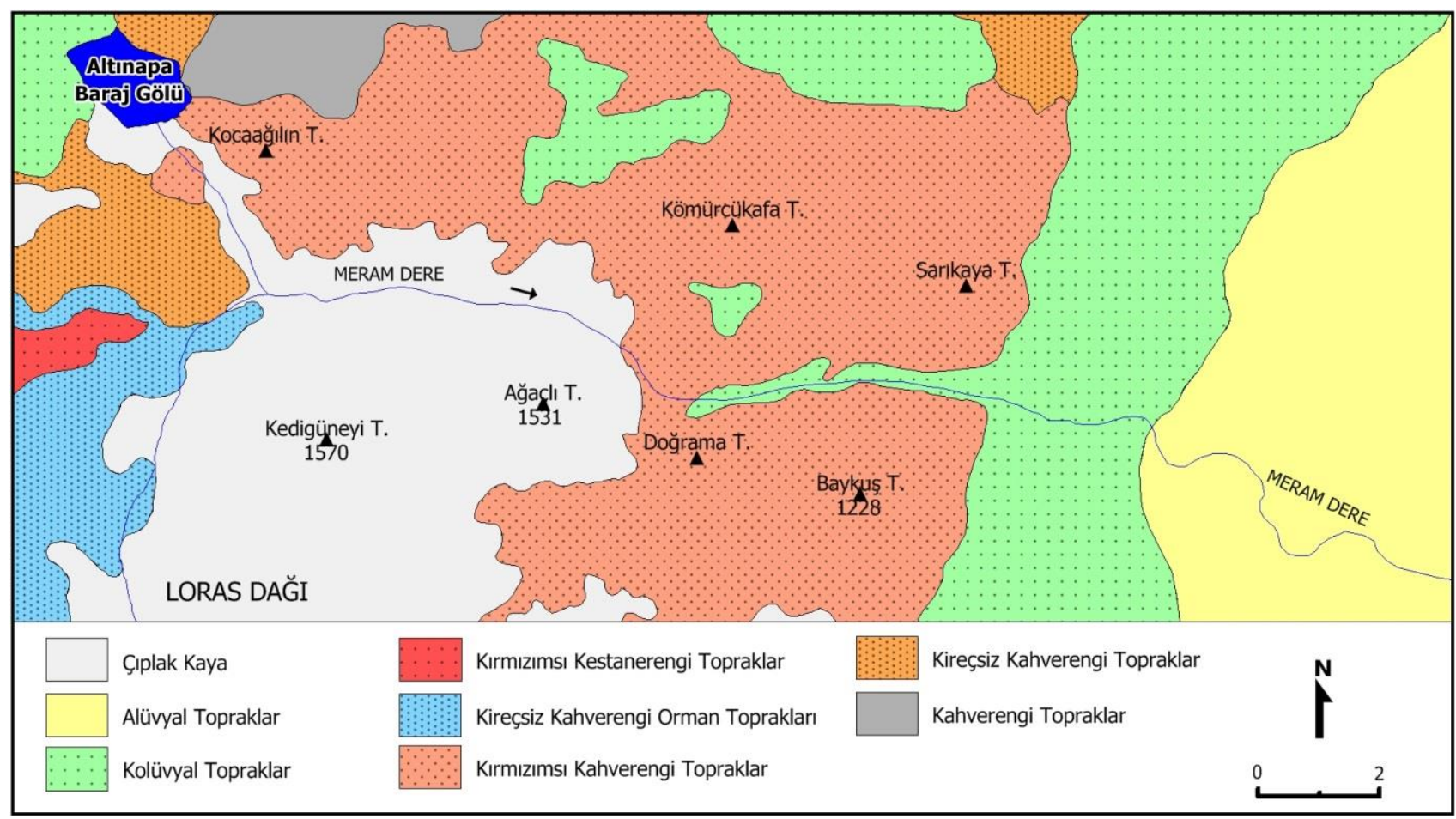

Şekil 3. Meram Dere Vadisi ve Çevresinin Toprak Haritası (Tarım ve Köy İsleri Bakanlı̆̆ı, Köy Hiz. Müd., 1992'den Değiştirilerek).

Meram Dere ve çevresinde az nemli mezotermal, su eksiği yaz mevsiminde ve çok kuvvetli, okyanus etkisine çok yakın bir iklim hüküm sürmektedir. Yıllık ortalama yağış $340.3 \mathrm{~mm}$, yıllık ortalama sıcaklık $11.6^{\circ} \mathrm{C}$ olarak tespit edilmiştir. Meram Dere Vadisi ve çevresinde yıllık rüzgar yönü incelendiğinde en yüksek frekansa NNE (11.88) ve N (11.75), yönlü rüzgarlar sahiptir (Meteoroloji Gn., Müd. 2018).

Meram Dere, kaynağını Aladağ (2339 m), Morbel, Akçal (1846 m) ve İtdişi (1920 m) tepelerinden alır. Buradan Uluçay Deresi adı ile doğar. Doğu ve Güneydoğu doğrultusunda akarak Darboğaz, Kışla, Hüyük, Dilekçi, Ulumuhsine, Küçükmuhsine, Kubbe, Sulu ve Han derelerini alarak Altınapa Baraj Gölü’ne ulaşır. Baraj Gölü’nden itibaren Meram Dere adını alarak Meram Dere Vadisi’nde akışını sürdürür. Meram Dere, Altınapa Barajı'ndan itibaren önce kuzey-güney yönünde ilerler. Daha sonra doğuya doğru dönerek Konya Ovası'na ulaşır.

Meram Dere'nin akım özellikleri doğal olmaktan uzaktır. Altınapa Barajı denetiminde olan derenin akımında yıl içerisinde bir seviye yükselmesi (Mart-Mayıs), bir de seviye alçalması (Temmuz-Eylül) meydana gelir (Orhon ve diğerleri, 1993; D.S.İ., IV. Böl. Müd., 2010). Karların eridiği döneme tekabül eden bahar aylarında kabarma, yağışların azalmasına bağlı olarak da yaz aylarında bir seviye düşmesi görülür.

Sonuç olarak Meram Dere Vadisi, floristik yapı bakımından ilginç özellikler göstermektedir. Bu özelliklerin ortaya çıkmasında doğal faktörlerin etkileri görülmektedir. Özellikle Meram Dere Vadisi’nin doğu-batı yönlü uzantılı yüksek dağlık ve tepelik alanlarla çevrili bir yapı oluşturması kuzey sektörlü rüzgârların vadiye ulaşmasını nispeten engellemektedir. Böylece nem ve sıcaklık şartları üzerinde olumlu bir etki oluşmakta ve sahanın bir mikroklima özelliği göstermesine yol açmaktadır. Bu durum, bitki örtüsü üzerine olumlu yönde yansımaktadır. Diğer önemli bir özellik ise jeolojik yapıyı oluşturan ana kayanın tabiatından kaynaklanmaktadır. Farklı jeolojik dönemlere ait kalker, ofiolit, peridotit, gabro, serpantinit, radyolorit, kumtaşı, silttaşı, ve volkanit gibi unsurların, sahada bulunan toprak oluşumu ve özelliklerini etkilemesi bitki örtüsünün de niteliğinin değişmesine neden olmuştur.

\subsection{Meram Dere Vadisi'nin Floristik Özelliklerine Etki Eden Antropojenik Faktörler}

Meram Dere Vadisi'nin floristik özelliklerine olumsuz yönde etki eden faktörler içerisinde antropojenik etkiler ön plana çıkmaktadır. Bu etkilerin başında Meram Dere Vadisi'nin yerleşim birimlerine yakın olması ve vadinin birçok kesiminin tarım amaçlı kullanılması 


\section{Avrupa Bilim ve Teknoloji Dergisi}

gelmektedir. Vadinin meyvecilik, bağcılık gibi zirai faaliyetlere uygun olması, doğal bitki örtüsünün tahrip olmasına zemin hazırlamıştır. $\mathrm{Bu}$ durum bitki örtüsü üzerinde bir dezavantaj olarak ortaya çıkmıştır. Beşeri faktörlerin diğer önemli etkilerinden birisi de sürü otlatmacılığıdır. Ayrıca araştırma sahasını oluşturan vadinin içerisinde doğu batı yönlü bir yol güzergâhının bulunması da bitki örtüsünün doğal gelişimini olumsuz yönde etkileyen diğer bir faktördür. Bu şartlar, vadi ve çevresindeki doğal bitki örtüsünün yatay ve dikey yöndeki dağılış sınırlarının ortaya çıkmasında etkili olmaktadır.

Araştırma sahasında yer yer bozuk orman kalıntılarının varlığını sürdürmesi bu kesimlerin geçmiş dönemlerde ormanlarla kaplı olduğunu göstermektedir. Bu ormanlar daha çok yaprak döken ağaçlardan oluşmaktadır. Bu bölgede doğal bitki örtüsü uzun sürede varlığını sürdürebilecek özellikte değildir. Daha çok step özelliğini yansıtmaktadır. Araştırma sahasında ormandan arta kalan kesimlerde çalı vejetasyonu yer yer hâkim durumdadır.

\subsection{Meram Dere Vadisi’nin Floristik Özellikleri}

Meram Dere Vadisi ve çevresinde orman, çalı ve step vejetasyonu görülmektedir. Bu vejetasyon tiplerinin yanı sıra akarsu kenarlarında (Meram Dere Vadisi tabanında ve yakın çevresinde) nemcil bir vejetasyonun varlığından da söz etmek yerinde olacaktır. Vadi yamaçlarına doğru kurakçıl çalı ve orman vejetasyonu hâkim durumdayken, plato yüzeylerinde orman ağaçları, çalılar ve step vejetasyonunun yoğunlaştığı görülmektedir. Yerleşim alanlarına yakın kesimlerde ise kültür bitkilerinin çeşitliliği vadinin ekolojik özelliklerini yansıtması bakımından önem arz etmektedir.

Orman vejetasyonu, küçük topluluklar halinde özellikle yayvan yapraklıların oluşturduğu yaprak döken ağaçlardan oluşmaktadır. Bu ağaçların esasını Meşe (Quercus sp.) türleri oluşturmaktadır. Kuraklığa ve yüksek sıcaklıklara dayanıklı olan bu türler bozuk orman görünümünde olup seyrek bir yapı oluşturmaktadır. Meşe toplulukları özellikle vadinin kuzey yamaçlarında erozyonun nispeten az olduğu ve vadi yamaçlarının iç bükey alanlarında nispeten toprağın muhafaza edildiği kesimlerde yoğunlaştığı görülmektedir (Şekil 4). Bu kesimlerin başında da; Ağaçlı Tepe'nin (1531 m) batısı, Boztaşlı Tepe'nin kuzey ve doğusu (1500-1550 m), Sineklibel Mevkii ve batısı gelmektedir (Şekil 5). Meşe toplulukları bazen Tüylü meşe (Quercus pubescens), bazen de Makedonya meşesi (Quercus trojana) türlerinden oluşmaktadır. Meşe toplulukları arasında yer yer Katran ardıcı (Juniperus oxycedrus), Kokar ardıç (Juniperus foetidissima), Dağ muşmulası (Cotoneaster nummularia) gibi türler yer almaktadır. Bu kesimlerde kekik, adaçayı ve keven gibi türler açık alanlarda sık karşılaşılan ve geniş yayılışa sahip olan türler olarak ortaya çıkar. Yine kireçsiz kahverengi orman toprakları üzerinde bozuk ardıç toplulukları yer almaktadır. Bu topluluklar içerisinde en çok göze çarpan Katran ardıcı (Juniperus oxycedrus)'dır. Bu tür, çalımsı bir özellikte olmasına rağmen bu alanda yetişmesi buranın özel bir ortam olduğunu gösterir. Bu topluluklar, Orta Trias-Üst Jura dolomitik kalkerler ile Alt-Orta Trias kalkerler üzerinde gelişmektedirler (Şekil 6). Bu bitkiler araştırma sahasının güneybatı kesimlerinde yer alan Kirazlı Yayla'nın batı kesimleri ve Kayısılı Yayla etrafında seyrek ve bazen de münferit olarak yayılış göstermektedir. Vadinin güney kesimlerinde ise karaçam topluluklarının yayılışı ortaya çıkmaktadır. Karaçamlar bu alanda daha çok ağaçlandırma ile oluşturulan topluluklar halindedir.

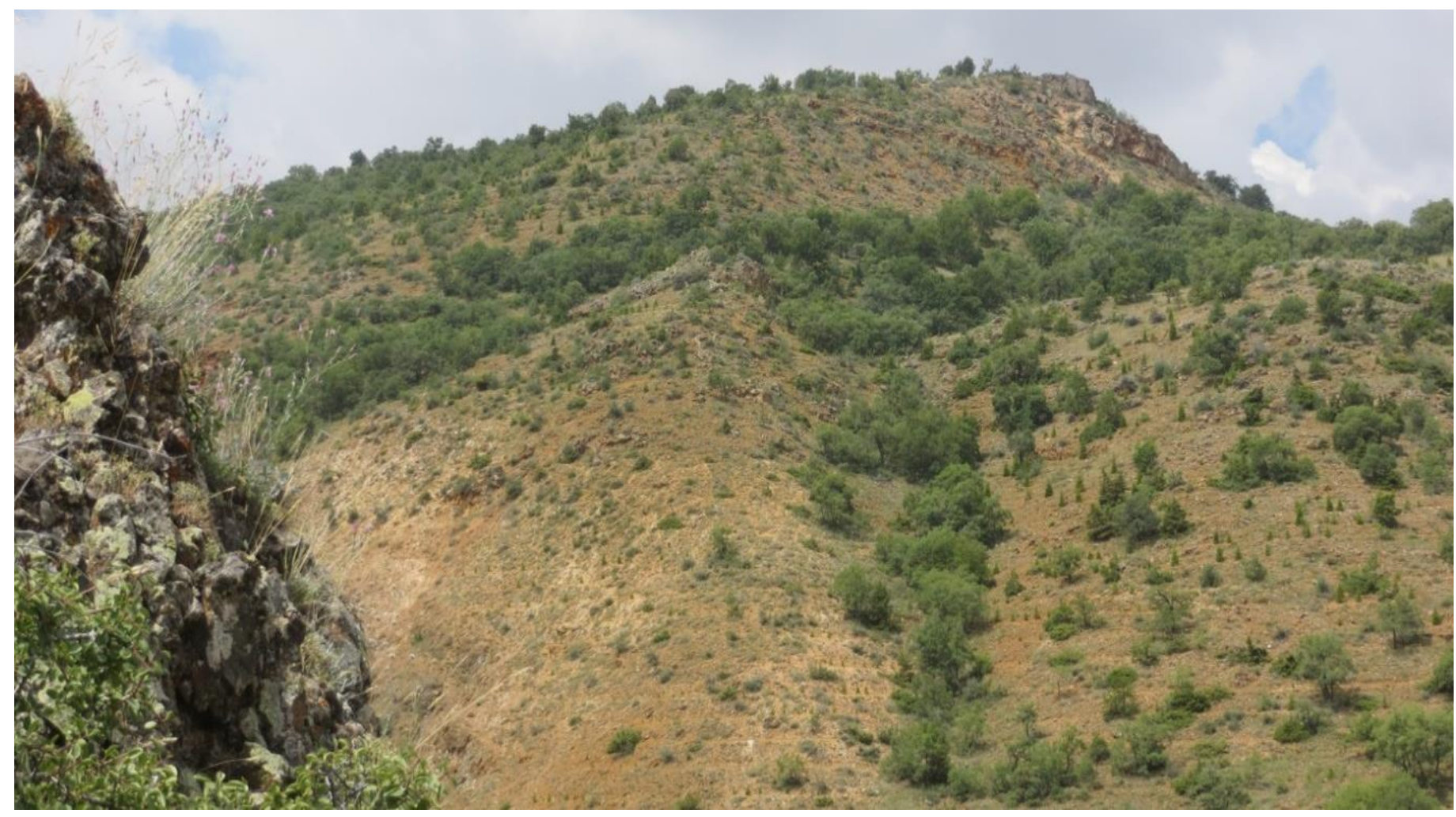

Şekil 4. Boztaşlı Tepe’nin Kuzey ve Doğu Yamaçlarındaki Meşe Toplulukları. Bu Topluluklarda, Hakim Meşe Türü, Tüylü Meşe (Quercus pubescens) Olmakla Beraber Yer Yer Makedonya Meşesi (Quercus trojana) Yer Almaktadır. 


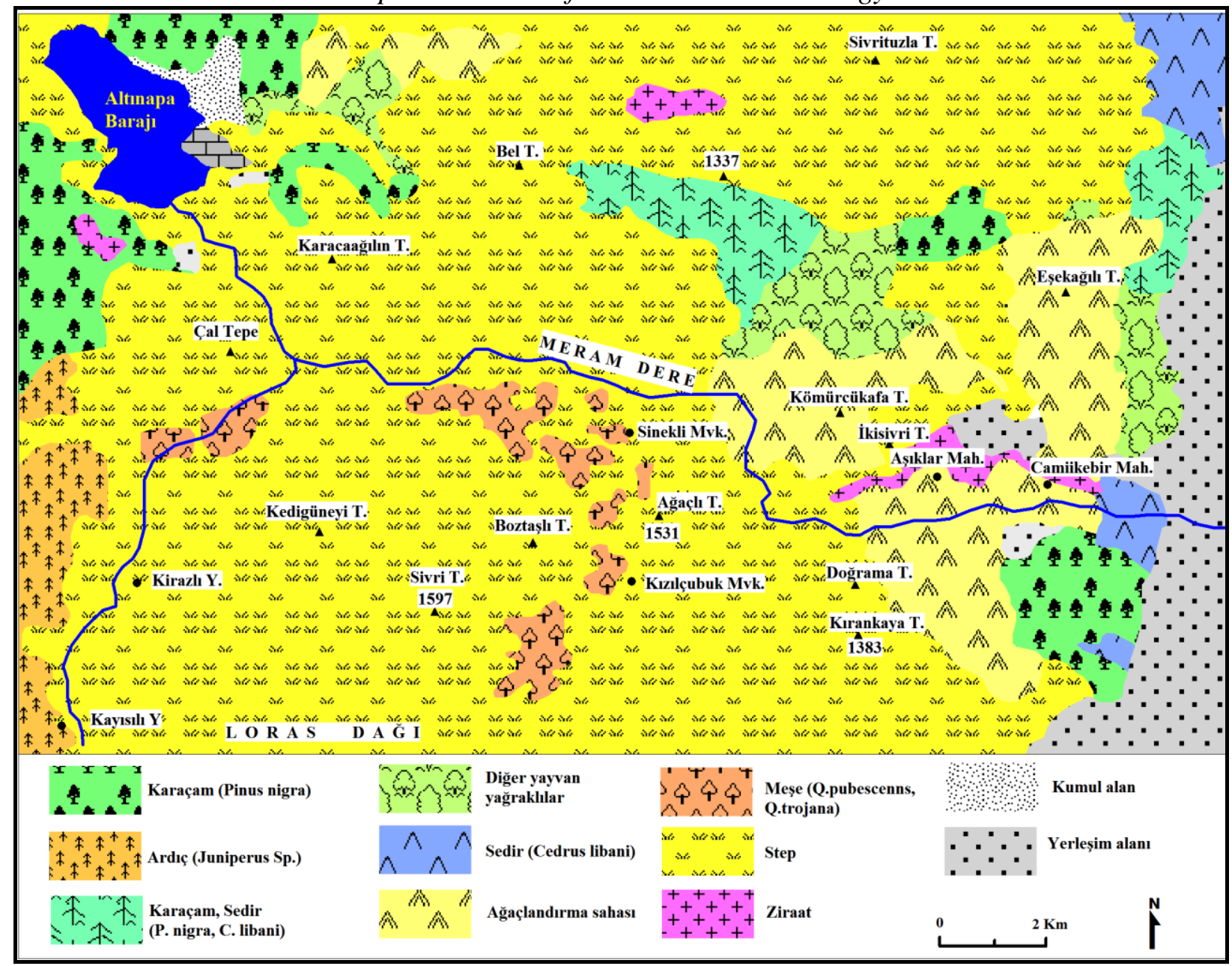

Şekil 5. Meram Dere Vadisi ve Çevresinde Bitki Türlerinin Yayılış Haritası.

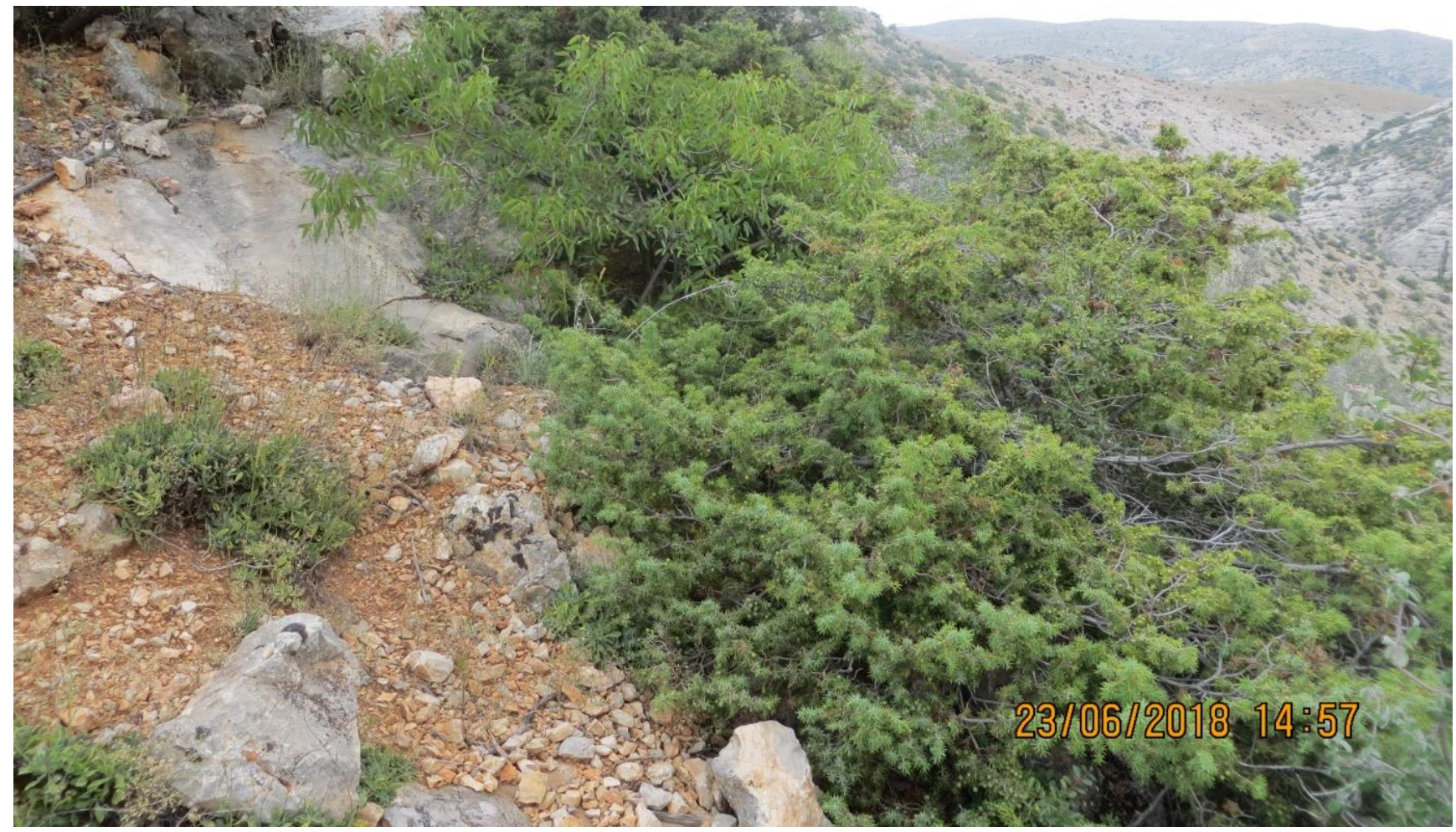

Şekil 6. Orta Trias-Üst Jura Dolomitik Kalkerler Üzerinde Gelişme Göstermiş Katran Ardıcı (Juniperus oxycedrus), Yer Yer Menengiç (Pistacia terebinthus) ile Karma Oluşturur. 


\section{Avrupa Bilim ve Teknoloji Dergisi}

Araştırma sahasında yayılış gösteren diğer bir formasyon, çalı vejetasyonudur. Özellikle vadinin güney yamaçlarında yayılış gösteren Menengiç (Pistacia terebinthus) ilginç bir şekilde bu bölgede bulunmaktadır. Akdeniz elementi olan Menengiç (Pistacia terebinthus) çalı halinde sıklıkla rastlanan bir tür olarak bu kesimlerde topluluk oluşturmaktadır. Ofiolit kayaçların bulunduğu kesimlerde daha seyrek ve daha bodurlaşmış olarak gelişirken ofiolit kayaçların ortadan kalktığı ve kalker kayaçların başladığı kesimlerde Menengiç (Pistacia terebinthus)'in hem sayı olarak arttığı hem daha iyi bir fizyonomiye sahip olduğu görülmektedir (Şekil 7). Ayrıca bu tür kahverengi ve kırmızı kahverengi topraklar üzerinde yoğunlaşmaktadır. Menengiç (Pistacia terebinthus)'in bu kesimlerde yayılış göstermesi buranın bir mikroklima alanı olduğuna işaret etmektedir. Vadi boyunca doğu batı yönlü uzanan tepelerin adeta set halinde vadiyi çevrelemesi Meram Dere Vadisi'nin kuzey sektörlü hakim rüzgarlara kapalı bir konumda olmasına neden olmaktadır. Bu durum Kış aylarında ise kuytu bir alan oluşmasına imkân vermektedir.

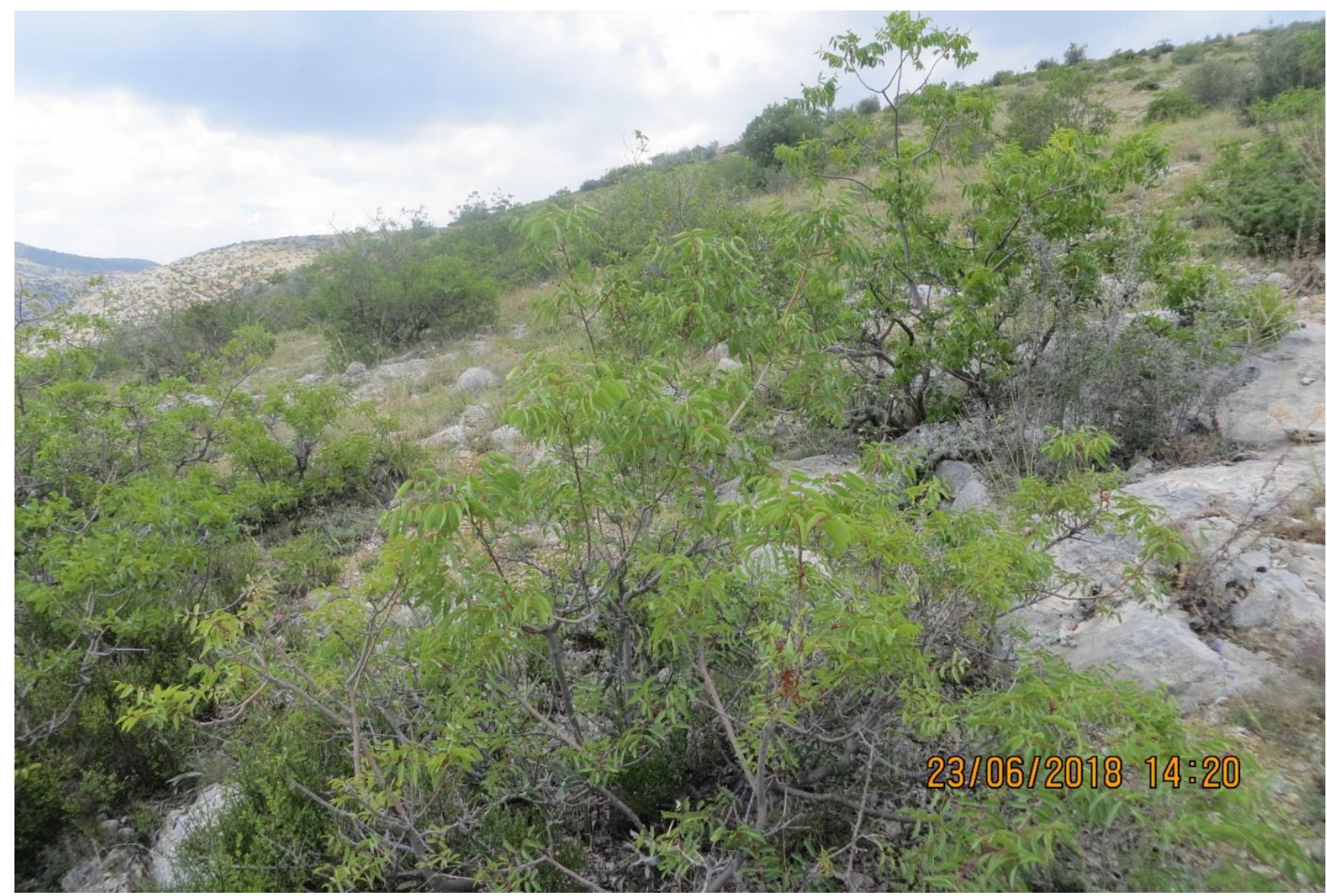

Şekil 7. Kocaağılın Tepe Güneyindeki Dolomitik Kalkerler Üzerinde Menengiç (Pistacia terebinthus)Topluluğu.

Menengiç (Pistacia terebinthus) özellikle Orta Trias-Üst Jura dolomitik kalkerler üzerinde iyi bir gelișme gösterirken Üst Kretase yaşlı kalker, çörtlü kalker ve ofiolit ile Üst Kretase-Alt Paleosen, hazburgit, dünit ve serpantin serileri üzerinde seyrekleşmekte, cılızlaşmakta ve daha bodur bir görünüm kazanmaktadır. Bu tür, daha çok kırmızı kahverengi topraklar ile çıplak kayaların arasında ve çatlaklarında birikmiş olan topraklar üzerinde de tutunabilmektedir. Bu alanda bulunan diğer bir ilginç çalı türü ise Derici sumağı (Rhus coriaria) dır. Bu türün Boztaşlı Tepe'nin kuzey yamaçlarında tali vadi sistemleri içerisinde topluluk oluşturduğu görülür (Şekil 8). Sumak bitkisi, coğrafi olarak; Akdeniz ikliminin hakim olduğu kesimlerde yayılış gösterir. Bu bitkinin burada bulunması buranın özel bir ortam olduğuna işaret eder. 


\section{European Journal of Science and Technology}

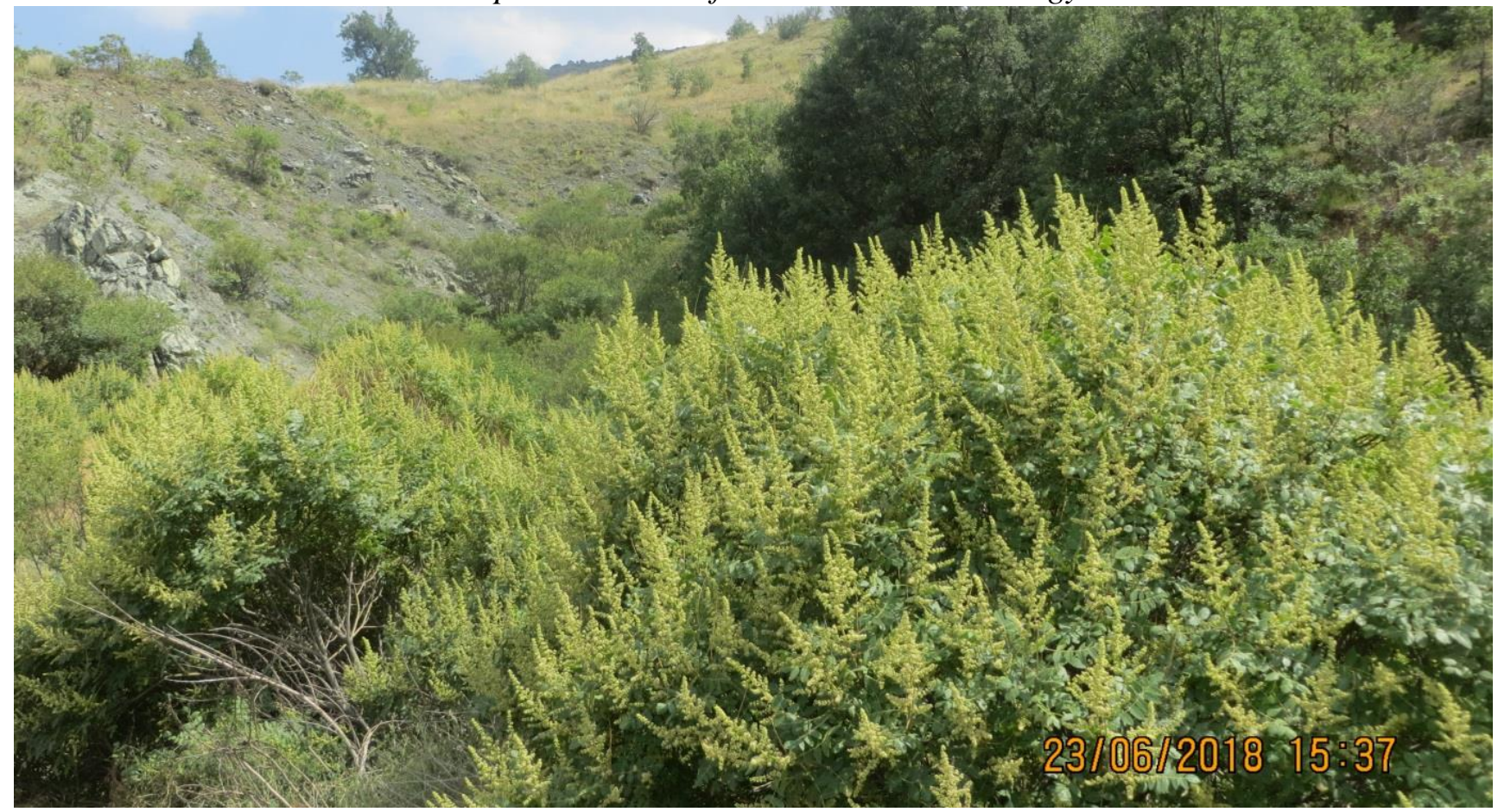

Şekil 8. Boztaşlı Tepe’nin Kuzey Kesimlerindeki Vadi Tabanında Yetişme İmkanı Bulmuş Derici Sumağı (Rhus coriaria).

Ayrıca Meram Dere Vadisi'nde Cehri (Rhamnus oleoides), Ova karaağacı (Ulmus minor), Dağ muşmulası (Cotoneaster nummularia), Anadolu alıcı (Crataegus orientalis), Alıç (Crataegus monogyna), Kuşburnu (Rosa canina), Yabani badem (Amygdalus orientalis), Sarı çiçekli yasemin (Jasmium fruticans), Çakal eriği (Prunus spinosa), Böğürtlen (Rubus discolor) gibi çalılar, orman ağaçlarının tahrip edildiği alanlarda yayılış göstermektedir. Bu türler, topluluk oluşturmaktan ziyade dağınık olarak bulunmaktadır. Bunların çoğu step sahalarında bulunan taşlı-çakıllı alanlarda tutunabilen ve özelliğini kaybetmiş türlerden oluşmaktadır. Ayrıca kayalık ve taşlık yerlerde Deniz üzümü (Ephedra majör, Şekil 9), Yabani defne (Daphne oleoides) gibi türlere de rastlanmaktadır.

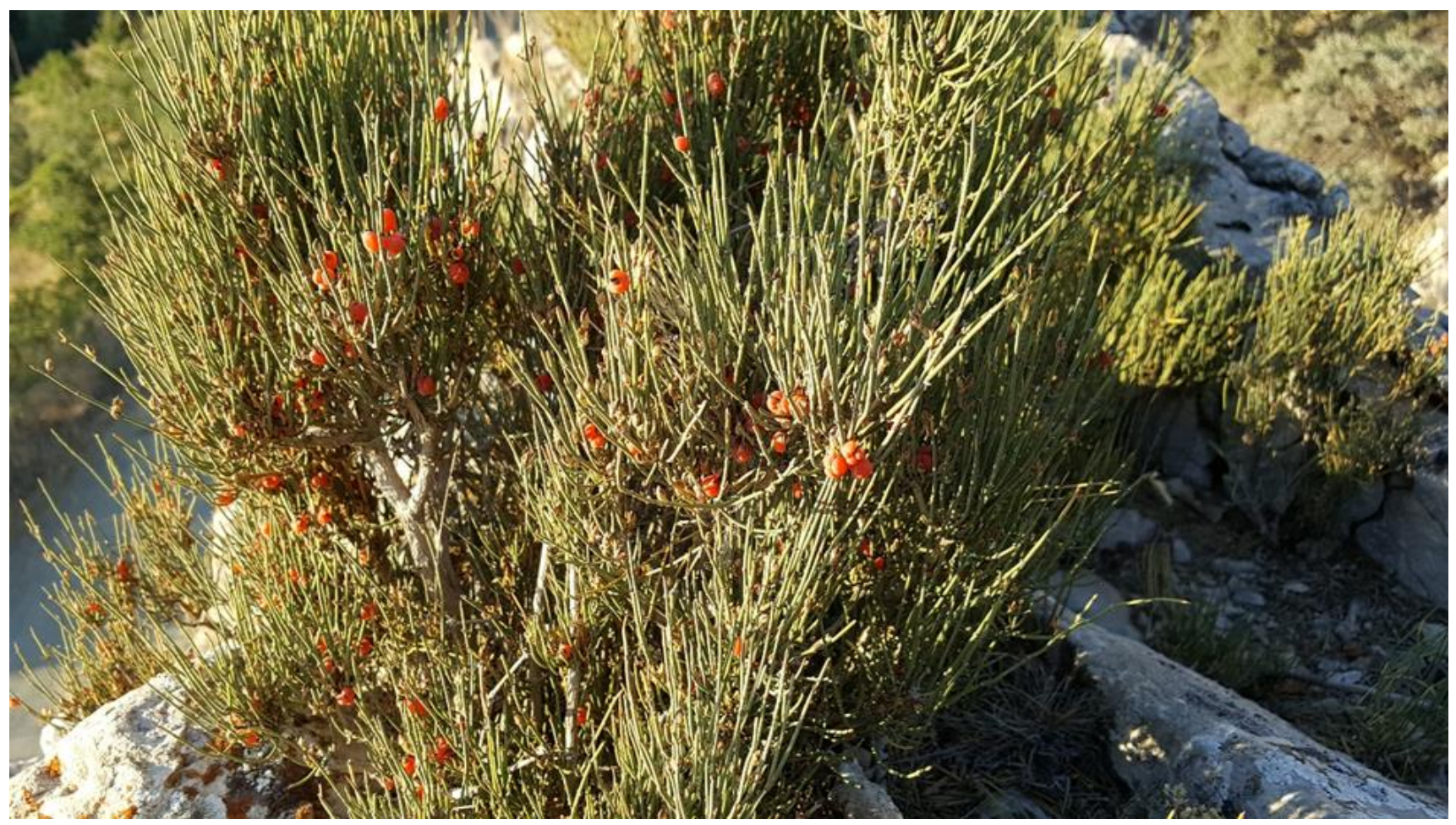

Şekil 9. Meram Dere Vadisi’nin Kayalık ve Taşlık Yamaçlarında Gelişme Göstermiş Deniz Üzümü (Ephedra majör).

Meram Dere Vadisi'ni çevreleyen alçak ve yüksek plato sahalarında orman ağaçları, çalılar ve otsu bitkilerden oluşan topluluklar; Ağaçlı Tepe, Boztaşlı Tepe ve Kedigüneyi Tepe ve çevresinde sıklıkla görülmektedir. Orman ağaçları ve çalılar arasında Yabani erik (Prunus divericata), Kuşburnu (Rosa canina), Ahlat (Pyrus elaeagnifolia), Saçlı meşe (Quercus cerris; Şekil 10), Tüylü meşe (Quercus 
pubescens; Şekil 11), Katran ardıcı (Juniperus oxycesrus), Boylu ardıç (Juniperus excelca), Cehri (Rhamnus oleoides), Alıç (Crataegus monogyna) Karaçam (Pinus nigra) yer almaktadır.

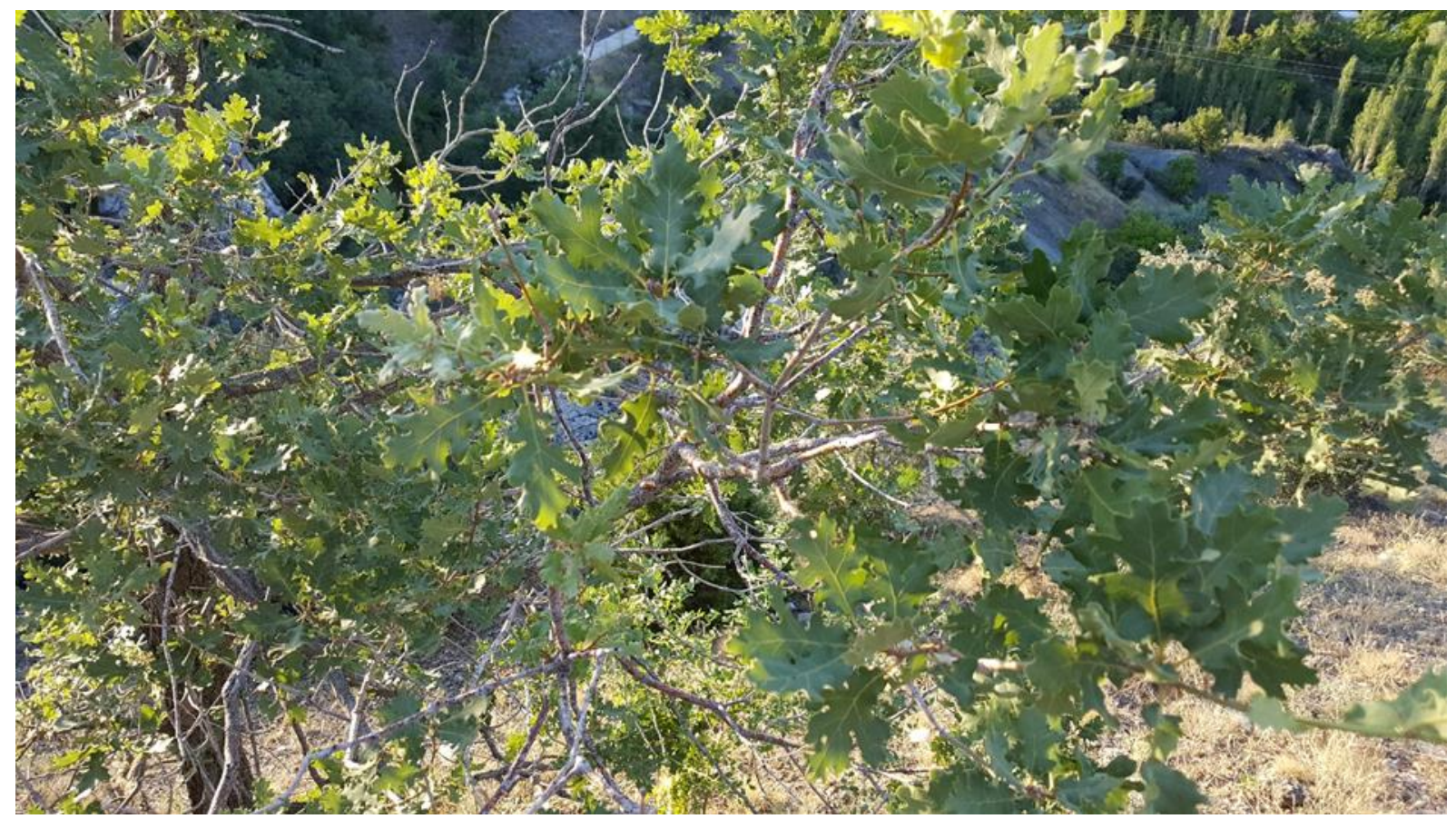

Şekil 10. Orman Ağaçları İ̧̧erisinde Yer Alan Saçlı Meşe (Quercus cerris), Plato Sahalarında Çalı ve Step Bitkiler Arasinda Yer Almaktadır.

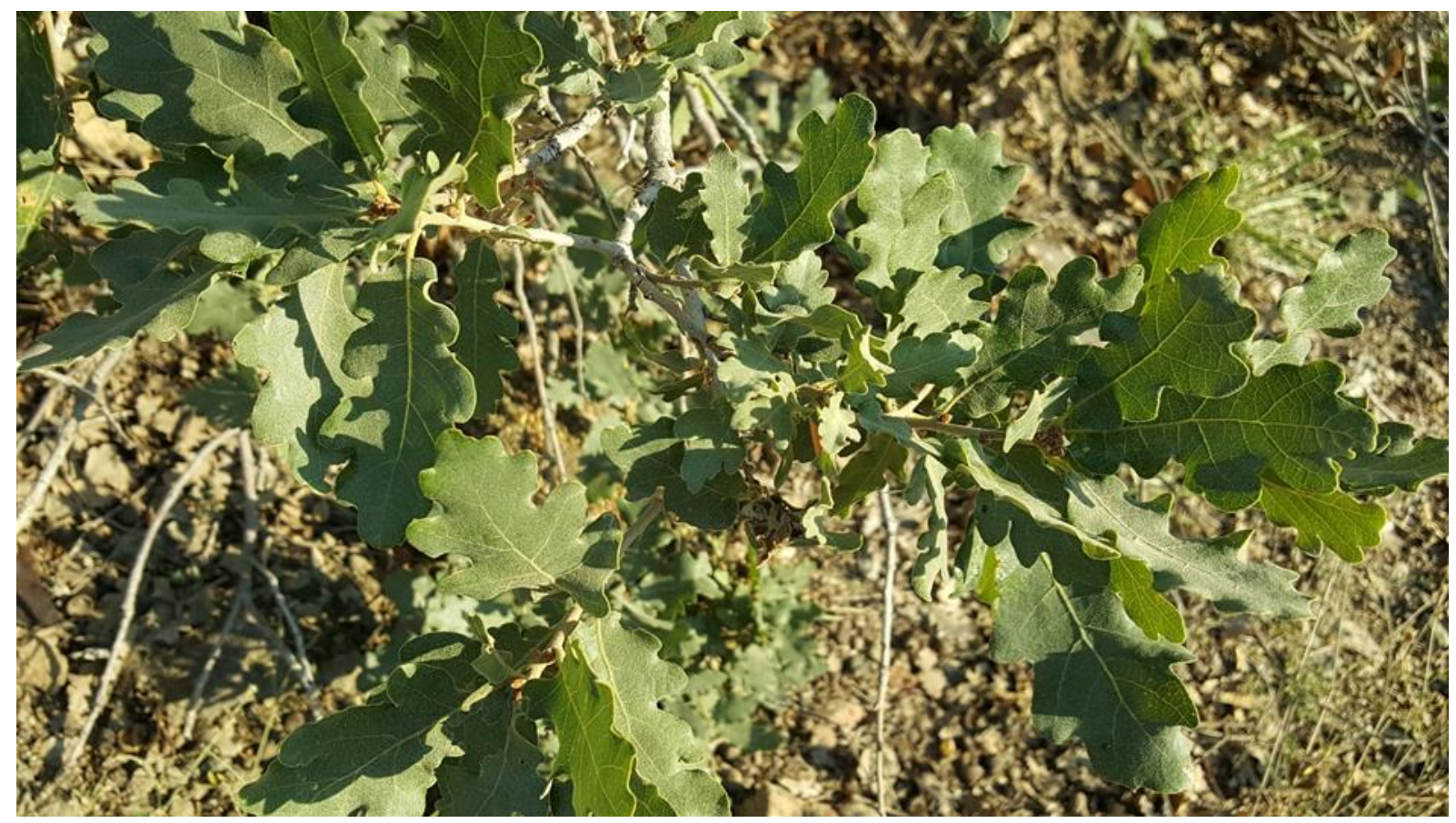

Şekil 11.Orman Ağaçları İçerisinde Yer Alan Tüğlü Meşe (Quercus pubescens), Plato Sahalarında Çalı ve Step Bitkiler Arasında Görülmektedir.

Meram Dere Vadisi ve çevresinde step vejetasyonu, en yaygın vejetasyon tipini oluşturur. Araştırma sahasında alçak dağ stepi hakim durumda olup vadinin doğusundaki dağlık tepelik kesimde 1000-1200 metre yükseklikteki kesimler ile ormansız alanlarda görülmektedir. 1200 metrenin üzerinde yer alan kesimler ise yüksek dağ stebi olarak ele alınabilir. Her iki yükselti katında da bitki örtüsü tahrip olmuş ve saha daha çok stepe dönüş̧e eğilimindedir. Sekonder bitkilerin hakim olduğu 1200 metre yüksekliğinin üzerindeki alanlarda meşe ve ardıç topluluklarının kalıntıları yer alır. Bu topluluklar içerisine bazı çalı türleri de iştirak eder. Primer vejetasyonun kalıntıları bu kesimlerde görülmez. Bu kesimler tamamen antropojenik step özelliği gösterir. Otsu formlardaki türler çok yoğun bir yayılişa sahiptir. Alçak dağ stepinin hakim türleri arasında Küre çiçeği (Globularia orientalis) ile tüy çiçekli Küre çiçeği (Globularia trichosantha) yer almaktadır. Bu türler daha çok taşlık ve kayalık kesimlerde sıklıkla görülürler. Ayrıca toprağı iyi bir şekilde örttüklerinden bu kesimlerde erozyonu azda olsa önleme özelliği taşırlar. Boz ot (Marribium parviflorum), Sığır kuyruğu (Verbascum sp), Tuzcul kirpidikeni 


\section{European Journal of Science and Technology}

(Acantholimon halophilum), Keçi geveni (Astragalus angustifolius; Şekil 12), Kardikeni (Acanthalimon ulicinum; Şekil 13), gibi daha bir çok tür step sahasının önemli bitkileridir. Sipil kekiği (Thymus sipyleus), Adaçayı (Salvia cryptantha), Buzağılık (Stipa arabica), Domuz ayrığı (Dactylis glomerata), gibi kserofit türler ise stepin önemli türlerini oluşturmaktadır. Yine araştırma sahasında özellikle kaya döküntüleri üzerinde gelişme gösteren Solucan otu (Pelargonium endlicherianum)'da dar bir alanda yayılış göstermektedir. Bu türler arasında Hanımeli (Lonicera etrusca), Yabani Defne (Daphne oleoides), Karamuk (Berberis crataegina) gibi çalılar da yer almaktadır.

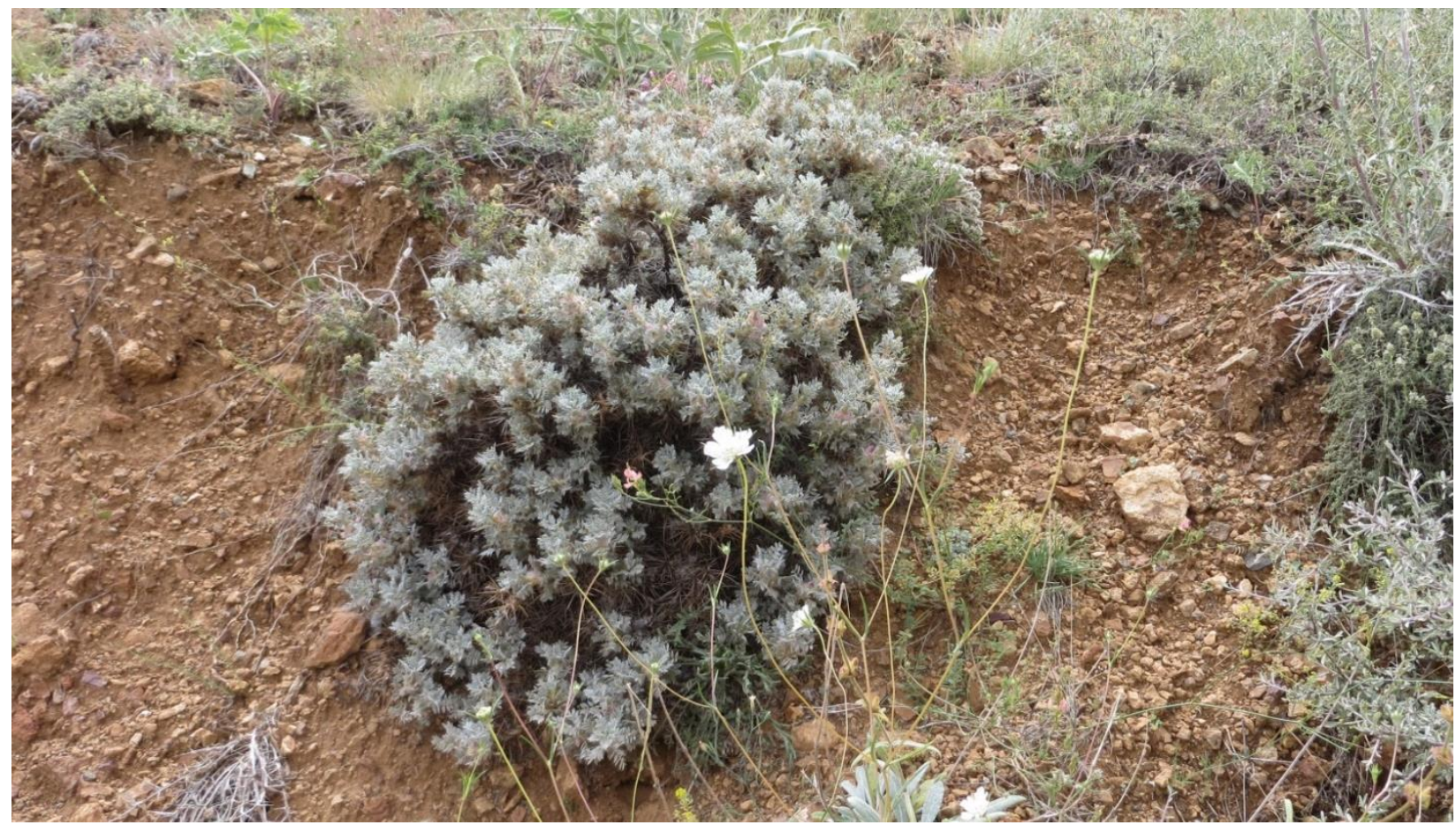

Şekil 12. Meram Dere Vadi Yamacında (Sinekli Mevkii), Keçi Geveni (Astragalus angustifolius).

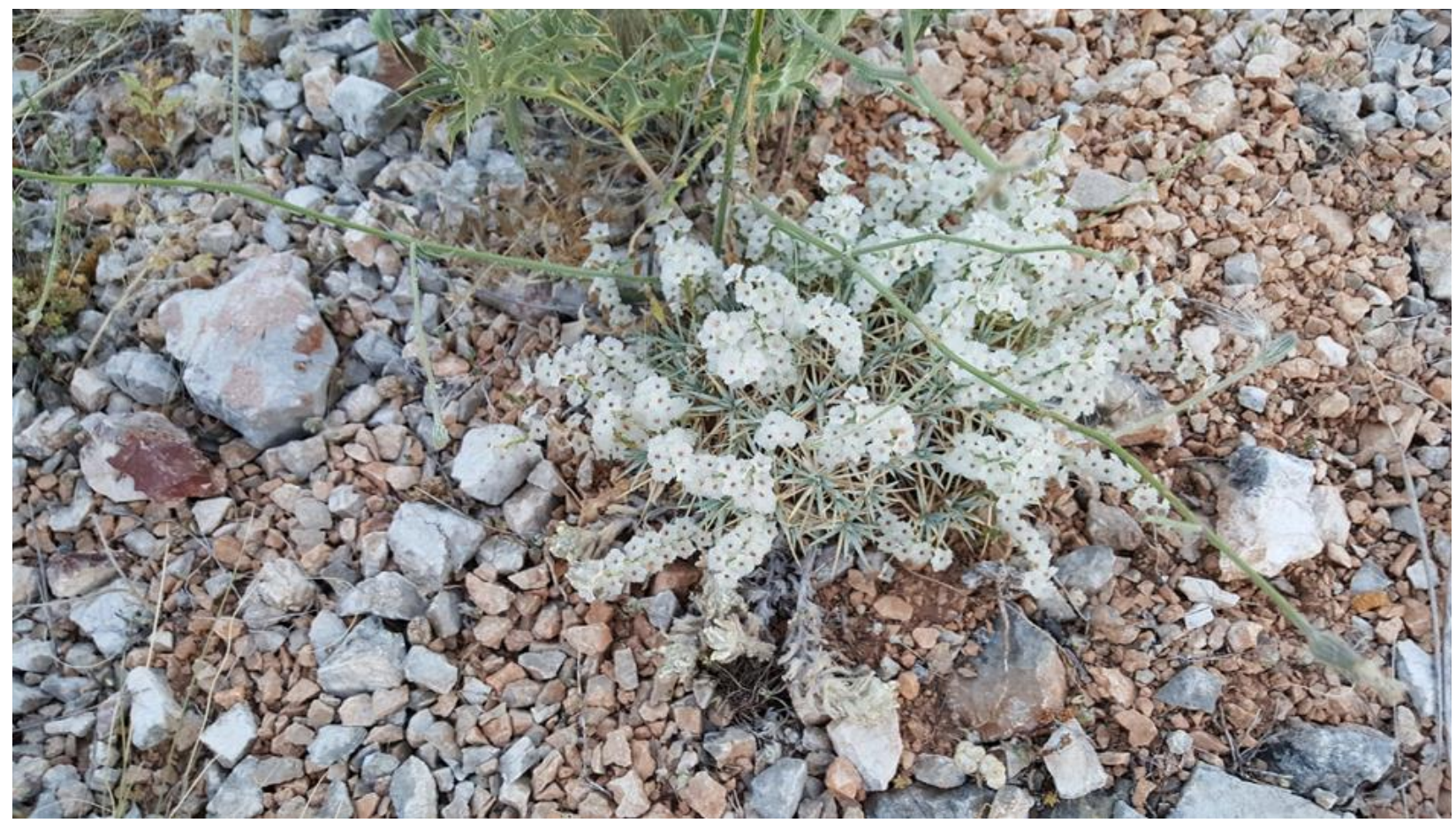

Şekil 13. Meram Dere Vadi Yamacındaki Taşlık Sahalarda Görülen Kar Dikeni (Acanthalimon ulicinum).

Meram Dere vadi tabanında 1060-1220 metreler arasında birçok yayvan yapraklı nemcil türün bulunduğu da görülmektedir. Bu türler Meram Dere Vadisi boyunca yayılıș göstermektedir. Derede yaz aylarında suyun bulunmaması, bu türlerin gelişimini olumsuz yönde etkilemiştir. Ancak vadinin yer yer daraldığı eşik sahalarının mikroklima özelliği göstermesi higrofil vejetasyonun nispeten korunmasına neden olmuştur (Şekil 14). Bu kesimlerde daha çok Ak sögüt (Salix alba.), Kara kavak (Populus nigra) Yabani iğde (Elaeagnus angustifolia), Doğu çınarı (Platanus orientalis), Ceviz (Juglans regia), Badem (Amydalus orientalis), Böğürtlen (Rubus fruticosus) gibi ağaçların yayılışı görülmektedir. Dere kenarında toprak neminin biraz daha yüksek olduğu kesimlerde ise Kamış (Phragmites australis), Adi dişbudak (Fraxinus excelsior), Yabani nane (Mentha spicata) gibi bitkilerin yayılışı dikkat çekmektedir. 


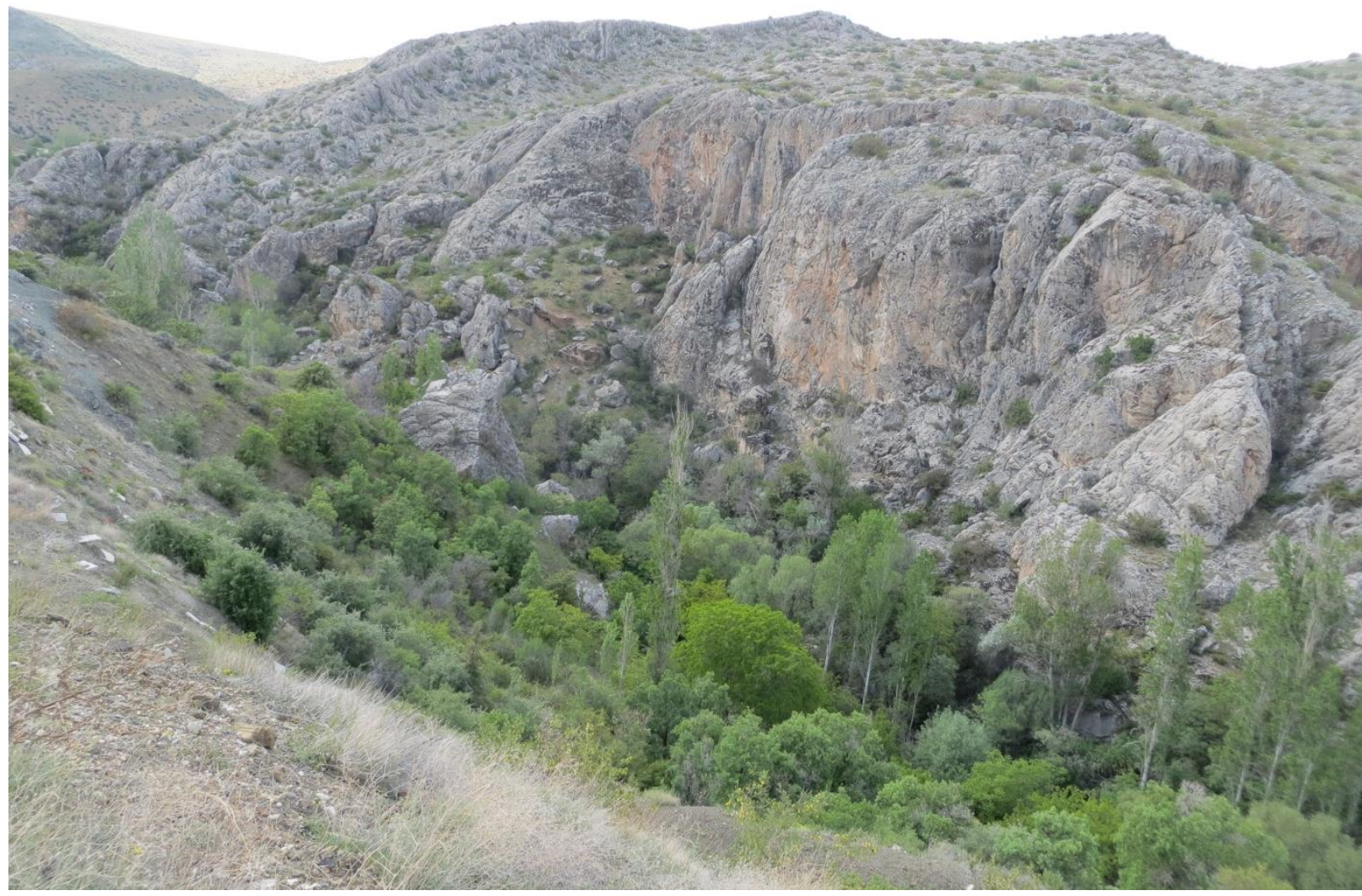

Şekil 14. Meram Dere Vadisi’nde (Sinekli Mevkii Kuzeyi) Gelişme Göstermiş Higrofil Vejetasyonun Genel Görünüşü.

Araştırma sahasında kültür bitkileri yetiştirmek için geniş düzlükler bulunmamaktadır. Ancak Dereaşıklar, Derecamiikebir mahallelerinin bulunduğu kesimdeki vadi tabanında meyve ve sebze tarımı yapılmaktadır. Toprak ve su şartlarının elverişli olduğu bu kesimlerde Asma (Vitis vinifera), Ak dut (Morus alba), Kara dut (Morus nigra), Ceviz (Junglans regia), Yaban elmas1 (Malus sylvestris), Yabani kiraz (Cerasus avium) gibi meyve türleri yetiştirilmektedir.

\section{Sonuç}

Araştırma sahası floristik yapı bakımından ilginç özelikler göstermektedir. Bu özelliklerin ortaya çıkmasında doğal ve antropojenik faktörlerin etkileri görülmektedir. Özellikle Meram Dere Vadisi'nin doğu-batı yönlü uzantılı yüksek dağlık ve platoluk alanlarla çevrili bir yapı oluşturması bu sahanın bir mikroklima özelliği göstermesine yol açmıştır. Bu durum, bitki örtüsünü olumlu yönde etkilemiştir. Akdeniz elementi olan Menengiç (Pistacia terebinthus) sıklıkla rastlanan bir tür olarak bu kesimlerde topluluk halinde yer almaktadır. Ayrıca farklı jeolojik dönemlere ait ana kaya üzerinde oluşmuş topraklar, bitki örtüsünün niteliğinin değişmesine neden olmuştur. Menengiç (Pistacia terebinthus) ofiolit kayaçların bulunduğu kesimlerde daha seyrek ve daha bodurlaşmış olarak gelişirken; kalker, dolomitik kalker anakaya üzerinde hem sayı olarak artmış, hem de daha iyi bir fizyonomiye sahip olduğu tespit edilmiştir.

Araştırma sahasında bitki örtüsü üzerine olumsuz yönde etki eden faktörler içerisinde antropojenik etki ön plana çıkmaktadır. Bu etkilerin başında, Meram Dere Vadisi'nin yerleşim birimlerine yakın olması ve vadinin birçok kesiminin tarım amaçlı kullanılması gelmektedir. Vadinin meyvecilik, bağcılık gibi zirai faaliyetlere uygun olması doğal bitki örtüsünün tahrip olmasına zemin hazırlamıştır. $\mathrm{Bu}$ durum bitki örtüsü üzerinde bir dezavantaj olarak ortaya çıkmıştır. Beşeri faktörlerin diğer önemli etkilerinden birisi de sürü otlatmacılığıdır. Ayrıca araştırma sahasını oluşturan vadinin içerisinde doğu batı yönlü bir yol güzergâhının bulunması da bitki örtüsünün doğal gelişimini olumsuz yönde etkileyen bir diğer faktördür. Bu şartlar, vadi ve çevresindeki doğal bitki örtüsünün yatay ve dikey yöndeki dağılış sınırlarının ortaya çıkmasında etkili olmaktadır.

Meram Dere Vadisi ve çevresinde orman, çalı ve step vejetasyonu görülmektedir. Meram Dere vadi tabanında ve yakın çevresinde nemcil; vadi yamaçlarına doğru kurakçıl çalı ve orman; plato yüzeylerinde orman ağaçları, çalı ve step vejetasyonunun yoğunlaştığı görülmektedir.

Orman vejetasyonu, küçük topluluklar halinde özellikle yayvan yapraklıların oluşturduğu yaprak döken ağaçlardan oluşmaktadır. Bu ağaç türleri arasında Tüylü meşe (Quercus pubescens), Makedonya meşesi (Quercus trojana) hakim durumdadır. Bazı kesimlerde de meşe toplulukları arasında Katran ardıcı (Juniperus oxycedrus), Kokar ardıç (Juniperus foetidissima), Dă̆ muşmulası (Cotoneaster nummularia) gibi türler yer almaktadır. Çalı vejetasyonu çeşitli türlerden oluşmaktadır. Özellikle vadinin güney yamaçlarında yayılış gösteren Menengiç (Pistacia terebinthus) ilginç bir şekilde bu bölgede bulunmaktadır. Menengiç (Pistacia terebinthus) Orta Trias-Üst Jura dolomitik kalkerler üzerinde iyi bir gelişme gösterirken Üst Kretase yaşlı kalker, çörtlü kalker ve ofiolit ile Üst Kretase-alt Paleosen, hazburgit, dünit ve serpantin serileri üzerinde seyrekleşmekte, cılızlaşmakta ve daha bodur bir görünüm kazanmaktadır. Bu tür daha çok e-ISSN: 2148-2683 


\section{European Journal of Science and Technology}

kırmızı kahverengi topraklar ile çıplak kayaların arasında ve çatlaklarında birikmiş olan topraklar üzerinde de tutunabilmektedir. Bu alanda bulunan diğer bir ilginç çalı türü ise Derici sumağı (Rhus coriaria) dır. Sumak bitkisi, coğrafi olarak; Akdeniz ikliminin hakim olduğu kesimlerde daha çok yayılış gösterir. Ayrıca Meram Dere Vadisi'nde Cehri (Rhamnus oleoides), Ova karaağacı (Ulmus minor), Dağ muşmulası (Cotoneaster nummularia), Anadolu alıcı (Crataegus orientalis), Alıç (Crataegus monogyna), Kuşburnu (Rosa canina), Yabani badem (Amygdalus orientalis), Sarı çiçekli yasemin (Jasmium fruticans), Çakal eriği (Prunus spinosa), Böğürtlen (Rubus discolor) gibi çalılar orman ağaçlarının tahrip edildiği alanlarda yayılış göstermektedir. Bu türler topluluk oluşturmaktan ziyade dağınık olarak bulunmaktadır.

Meram Dere Vadisi ve çevresinde step vejetasyonu, en yaygın vejetasyon tipini oluşturur. Araştırma sahasında step; alçak ve yüksek dağ stepi olmak üzere iki şekilde görülmektedir. Alçak dağ stebi vadinin doğusundaki dağlık tepelik kesimde 1000-1200 metre yükseklikteki kesimler ile ormansız alanlarda görülmektedir. Yüksek dağ stebine 1200 metrenin üzerinde yer alan kesimlerde rastlanır. Her iki yükselti katında da bitki örtüsü tahrip olmuştur ve saha daha çok stepe dönüşme eğilimindedir. Sekonder bitkilerin hakim olduğu 1200 metre yüksekliğinin üzerindeki alanlarda meşe ve ardıç topluluklarının kalıntıları yer alır. Bu topluluklar içerisine bazı çalı türleri de iştirak eder. Primer vejetasyonun kalıntıları bu kesimlerde görülmez. Bu kesimler tamamen antropojenik step özelliği gösterir. Otsu formlardaki türler çok yoğun bir yayıllşa sahiptir. Alçak dağ stepinin hakim türleri: Küre çiçeği (Globularia orientalis), Tüy çiçekli küre çiçeği (Globularia trichosantha), Boz ot (Marribium parviflorum), Sığır kuyruğu (Verbascum sp,), Tuzcul kirpidikeni (Acantholimon halophilum), Kardikeni (Acanthalimon ulicinum), Keçi geveni (Astragalus angustifolius), Sipil kekiği (Thymus sipyleus), Adaçayı (Salvia cryptantha), Buzağılık (Stipa arabica), Domuz ayrığı (Dactylis glomerata), Solucan otu (Pelargonium endlicherianum)'dur.

Meram Dere vadi tabanında 1060-1220 metreler arasında birçok yayvan yapraklı nemcil türün bulunduğu da görülmektedir. Bu türler arasında Ak söğüt (Salix alba.), Kara kavak (Populus nigra) Yabani iğde (Elaeagnus angustifolia), Doğu çınarı (Platanus orientalis), Ceviz (Juglans regia), Badem (Amydalus orientalis), Bögürtlen (Rubus fruticosus) Kamış (Phragmites australis), Adi dişbudak (Fraxinus excelsior), Yabani nane (Mentha spicata) dikkati çekmektedir.

Sonuç olarak Meram Dere Vadisi'nin floristik özelliklerinin şekillenmesinde mikroklima, topografya, anakaya, toprak ve hidroğrafik şartların yanında antropojenik faktörlerin de etkili olduğu görülmektedir. Vadide menengiç (Pistacia terebinthus) bitkisinin topluluk halinde yer alması dikkat çeken bir diğer olaydır. Meram Dere Vadisi'nin sahip olduğu floristik özellikler dikkate alınarak, bu vadinin "Yeşil Vadi" halinde projelendirilmesi gerektiği inancındayız. Bu konuda:

-Doğal bitki örtüsü korunmalı ve geliştirilmeli,

-Altınapa Barajı ile Meram Mesire yeri arasındaki Meram Dere yatağı 1slah edilmeli

-Meram Dere Vadisi ve çevresinde, yerleşim mekanlarına izin verilmemeli,

-Önceden var olan ağıl ve yayla yerleşmeleri korunmalı,

-Meram Dere Vadi tabanını takiben yürüyüş güzergahları belirlenmeli,

-Vadi içerisinde ulaşım, doğaya zarar vermeyecek şekilde düzenlenmeli,

-Vadinin mikroklima özelliği dikkate alınarak Akdeniz ikliminde yetişen bazı bitki türleri yetiştirilmeli,

-Vadinin potansiyel değerleri dikkate alınarak "Yeşil Vadi Projesi”" olarak projelendirilmeli. Bu konuda belediyelerden ve üniversitelerden yardım alınmalıdır.

\section{Kaynakça}

Avcı, M. (1993-96). Göller Yöresi Batı Kesiminde İklim ile Bitki Örtüsü Arasındaki İlişkiler. Coğrafya Dergisi, Sayı 4, s.143-216, İstanbul.

Avcı, M. (1998a), Ilgaz Dağları ve Çevresinin Bitki Coğrafyası 1. (Bitki Örtüsünün Coğrafi Şartları), Coğrafya Dergisi, Sayı 6, s.137-216. İstanbul.

Avcı, M. (1998b). Ilgaz Dağları ve Çevresinin Bitki Coğrafyası II. (Bitki Örtüsünün Coğrafi Dağıılışı), Coğrafya Dergisi, Sayı 6, s.275344, İstanbul.

Bozyiğit, R. (2018). Takkelidağ. Çizgi Kitabevi Yayın no:834, Konya.

Bulduk, A.-Tekdere, M.-Topçuoğlu, A.T.-Solak, N., (2006). Konya İli Yerleşim Alanı ve Civarının Jeoloji Ön Raporu, Konya Büyükşehir Belediyesi, KOSKİ, Konya.

Çetik, R., 1985, Türkiye'nin Vejetasyonu I. İç Anadolu'nun Vejetasyonu ve Ekolojisi., S.Ü. Fen-Ed. Fak. Yay. No:7, Konya.

Dural, H.-Ekim, T., 1984, Takkalı Dağının (Konya) Florası, S.Ü. Fen Ed. Fak. Fen Dergisi, Sayı:3, Konya.

DSİ IV. Bölge Müdürlüğ̈̈ (2010). Akım Gözlem Bülteni. Konya.

Göğer, E., Kıral, K. (1973). Kızılören Dolayının (Konya'nın Batııı) Genel Stratigrafisi. MTA Rapor No:5204 (Yayınlanmamış). Ankara.

Güyer, F., Günaydın, A.B., Akbulut, İ., Ak, S., Kurtman, T., Demirci, A.R., Akarsu, B., Emre, Ö., Durdu, M., Karakaş, M., Üyüklü, A., Yıldız, H. (1998). Konya İli Çevre Jeolojisi ve Doğal Kaynaklar. MTA Rap. No:42149, Ankara.

Günal, N. (1998-1999). Keçiboynuzunun Türkiye'deki Coğrafi Yayılışı, Ekolojik ve Floristik Özellikleri. Marmara Coğrafya Dergisi, Sayı 2, s.60-74, İstanbul.

Güngördü, M. (1985). Güney Marmara Bölümü (Doğu Kesimi) Bitki Örtüsünün Coğrafi Şartları, Coğrafya Dergisi, Sayı 1, s.77-94, İstanbul.

Kırbıyıkoğlu, M., (2003). Konya Havzası'nın Geç Kuaterner Evrimi, İst. Üniv. Sos.Bil. Enst. Coğrafya Anabilim Dalı (Doktora Tezi), İstanbul.

Meteoroloji Genel Müdürlüğü., (2018). Konya (Alan) İklim Verileri (1975-2017).

Süzer, C. Kul, H.H. Bilgin, F., (2011). Konya İli Meram İlçesi M28b14d Ve M28b13 Paftalarda İmar Planına Esas Jeolojik-Jeoteknolojik Etüt Raporu (Yayınlanmamış), Konya. 


\section{Avrupa Bilim ve Teknoloji Dergisi}

Şenel, M., Dalkılıç, H. (2016). 1/100 000 Türkiye Jeoloji Haritaları Serisi, Konya-M 27 Paftası No:227, Maden Tetkik Arama Genel Müdürlüğü, Jeoloji Etütler Dairesi, Ankara.

Şenel, M., Pehlivan, N. (2016). 1/100 000 Türkiye Jeoloji Haritaları Serisi, Konya-M 28 Paftası No:228, Maden Tetkik Arama Genel Müdürlüğü, Jeoloji Etütler Dairesi, Ankara.

Tarım ve Köy İşleri Bakanlı̆̆ı, Köy Hizmetleri Müdürlüğü, (1992). Konya İli Arazi Varlığı, Ankara.

Orhon, M., Esendal, S., Kazak, M. A. (1991). Türkiye'deki Barajlar, Ankara: Bayındırlık ve İskan Bakanlığı. 